\title{
Testing the Separation Hypothesis in Rural Java: Revisited
}

\section{Jangkung Handoyo Mulyo* and Seiichi Fukui*}

\section{ジャワ農村における分離特性仮説の再検討}

\author{
ジャンクン・ハンドヨ・ムリヨ（神戸大学） \\ 福 井 清一(神戸大学)
}

\begin{abstract}
発展途上国の農家家計に関する分離特性仮説の研究 は，すでに多くの研究者によって行われ，卧とんどの 国々に拈いては，分離特性が成立するという仮説が棄 却されたのであるが，インドネシアは例外的に棄却さ れなかった。

本稿の目的は, この仮説の妥当性について, 中部ジャ ワ・ジョクジャカルタ近郊農村に抢ける家計調查の結 果にもとづき，再検討したものである。

インドネシアを対象とした既往研究では, 実証方法と して, 労働需要と家計特性の相関関係の有無を検証す る方法が採用されているが, 本稿では, 学働の限界生 産力と賃金率の均等性を検証する接近法も合わせて試
\end{abstract}

みられた。また，理論的枠組みについても，既往研究 では, 農業生産に扮ける家族労働と雇用労働, 自家農 業と農外雇用に抬ける家族労働が完全代替的であると 仮定されたが、本稿では，自家農業に投入する家族労 働力と, その他労働力の不完全代替の可能性を容認し, 農村労働市場に扮ける需要制約の有無を別途検証でき る枠組みを用いた点に特徵がある。

分析の結果, 既往研究同様, 農村労働市場に打ける需 要制約の存在は認められなかったが, 分離特性仮説は 棄却された。この結果は, 過剩労働が存在しないにも かかわらず生産と家計消費の分離が認められないこと を示すものである。

\section{Introduction}

Indonesia has achieved remarkable economic development during the past three decades. During this period, the relative share of the labor force engaged in agricultural sector has not declined as much as its share of GDP. This has resulted in greater income disparity between the agricultural and non-agricultural sectors (Fukui [2005]).

To enhance labor productivity and reduce such income disparity, the Indonesian government will have to implement agricultural structural policies and enlarge the average farm size.

\footnotetext{
* Kobe University
}

However, the effectiveness of such structural policies depends on the farmers' responses to such policies under the existing factor market structure. We can predict that those structural policies which encourage the productivity of farmers will be very effective if farmers are profit-oriented under the competitive and perfect-factor markets. On the other hand, if factor markets are imperfect and/or farmers are not profit-oriented, such structural policies might not be so effective ${ }^{1)}$.

This separation theorem serves as a useful benchmark for examining the patterns of agricultural household behavior under the particular rural labor market structure. Its rejection has implications for the structure of the rural markets and household behavior 
(Udry [1996]).

In most developing countries where the hypothesis has been tested, it has been decisively rejected. However, Pitt and Rosenzweig (1986) and Benjamin (1992), who studied large sets of Indonesian data, found it difficult to reject the hypothesis completely.

The objective of this paper is to examine whether or not the production decisions of farm households are separable from the consumption decision. Also, it aims to determine whether or not farm households behave to maximize profit. This paper used the farm household panel data collected by the Japan Society for the Promotion of Science and the Directorate General for Higher Education of Indonesia (JSPS-DGHE) Core University Program in Central Java, Indonesia.

Much of the literature has been concerned with the relevance of the hypothesis of separation property or profit maximization. The existing literature on these topics can be categorized into two lines of empirical method. The first method is to test the efficiency of resource allocation or the equality of input price and marginal productivity. Kuroda and Yotopoulos [1978], Kuroda [1979], Lopez [1984], Jacoby [1993] and Abdulai and Regmi [2000] are the key papers in this area. The second line of empirical tests is concerned with the correlations between household characteristics, such as demographic factors, family assets and input demand (Strauss [1986], Pitt and Rozenzweig [1986], Benjamin [1992] and Udry [1996]).

In this paper, both lines of empirical methods are applied to test the hypothesis. The first approach used in this study is different from Kuroda's approach in the sense that hired labor is not taken to be a perfect substitute for family labor from the viewpoint of production technology and for off-farm labor from the perspective of preference. This is because recent studies cast doubt on the hypothesis of perfect substitutability (Deolalikar and Vijverberg [1987]), nor are the findings of the present study consistent with the perfect substitutability hypothesis as shown in the next section. Jacoby [1993] and Abdulai and Regmi [2000] examined the equality of wage and marginal productivity of labor by estimating the production function. Their method was not employed here, however, because it was not easy to obtain any good estimated results due to the multi-collinearity problem, and there is also difficulty in measuring quality of labor (Strauss and Thomas [1995]). In addition, Lopez [1984] used a more complicated joint estimation strategy but relies on a strong functional assumption, thus we decided not to follow his approach (Jacoby op. cit.).

The approaches of Benjamin [1992] and Udry [1996] are employed in the second approach to estimate the input demand function and examine the correlation between labor demand and individual household characteristics. However, this study used the panel data to test the separation hypothesis. Through the panel data analysis, unobserved individual effects can be estimated. Also, in this study family labor and off-farm labor were assumed to have different effects on preferences. In the same manner, family labor and hired labor were assumed to have different effects on production.

This paper is organized as follows. Section 2 describes the economic environment and the characteristics of sample households related to labor market and farm household behavior. We also show evidence of the imperfect substitutability of labor. In section 3 , we briefly explain an agricultural household model in which the family labor used for on-farm jobs is not perfectly substitutable by family labor used for offfarm jobs and hired labor for farming. This will then be followed by a discussion of the empirical models used to test the separation hypothesis and profit maximization hypothesis. Section 4 describes the results of the estimations which indicate that the separation hypothesis and the profit maximization hypothesis were rejected not because of labor market constraints but because of the non-substitutability of family labor and hired labor, and the different effects on preferences by family labor and off-farm labor. In the last section, a summary of the major estimation results, as well as some policy implications that can be drawn from them, is discussed. 


\section{Economic Environment and Characteristics of Sample Households}

The study area, which includes the Planggok and Somokaton hamlets, is located in the Sleman district. These two hamlets are situated about $10 \mathrm{~km}$ northwest of the city of Yogyakarta Special Province. About 45 households per year from 2000 to 2002 were interviewed through the random sampling method (Fukui et al. [2002]).

The irrigation conditions are better in Planggok than in Somokaton (Subejo and Iwamoto [2003]). The farmers in the Planggok Hamlet enjoy an abundant supply of water from the Mataram Canal throughout the year, and catfish farming is possible as well as triple rice cropping. On the other hand, in Somokaton, where a sufficient water supply cannot be expected because irrigation water is drawn from small springs, double cropping during the year or five cropping over a twoyear period is common. This is because the farmers sometimes encounter a water shortage problem during the second dry season.

The economic environment and the characteristics of the sample households are discussed subsequently in the next section.

\subsection{Farm Household Characteristics}

The sizes of the owned agricultural land and farms involved in this research are very small (Table 1). For instance, the average size of owned agricultural land is less than 0.2 ha although the average yield of rice in the normal year amounts to about 3.8 to 5.6 tons/crop/ ha. Therefore, in an attempt to maintain their living standard, small farmers work in the off-farm labor market and lease agricultural land from their neighbors.

Table 1. Characteristics of Sample Households

\begin{tabular}{|c|c|c|}
\hline Characteristics & Planggok hamlet & Somokaton hamlet \\
\hline Number of households & 18 & 27 \\
\hline Number of farm households & 17 & 24 \\
\hline Number of family labor (person/hh) & 2.56 & 2.81 \\
\hline Area of agric. ownedland (ha/hh): & 0.19 & 0.15 \\
\hline Paddy field & 0.16 & 0.14 \\
\hline Farm size (ha/hh) & 0.36 & 0.28 \\
\hline \multicolumn{3}{|l|}{ Land use (planted area; ha/hh): } \\
\hline Paddy & 0.97 & 0.52 \\
\hline Non-rice crop & 0 & 0.17 \\
\hline Crop intensity & 2.71 & 2.48 \\
\hline \multicolumn{3}{|l|}{ Yield of paddy (ton/ha/planting): } \\
\hline Rainy & 5.33 & 4.55 \\
\hline Dry I & 5.55 & 3.95 \\
\hline Dry II & 4.11 & 3.78 \\
\hline \multicolumn{3}{|c|}{ Average Farm Household Income (Rupiah/year): } \\
\hline Agricultural income & $5,679,491$ & $2,268,930$ \\
\hline a. Rice income & $2,274,033$ & $1,290,038$ \\
\hline b. Non-rice income & $3,405,458$ & 978,892 \\
\hline Off-farm income & $4,532,640$ & $5,208,333$ \\
\hline Remittance & 374,601 & 290,148 \\
\hline Farm household income & $10,586,732$ & $7,767,412$ \\
\hline \multicolumn{3}{|l|}{ Farm assets (excluding land): } \\
\hline Cow and buffalo (head/hh) & 0.11 & 0.44 \\
\hline Tractor owned (number/hh) & 0 & 0 \\
\hline Sprayer (number/hh) & 0.44 & 0.48 \\
\hline Thresher (number/hh) & 0.06 & 0 \\
\hline
\end{tabular}

Source: Farm Household Survey, 2002.

Note: Exchange rate in 2002 was US $\$ 1=$ Rupiah 8,940 
Agricultural income and off-farm income account for $43.3 \%$ and $53.1 \%$ of total household income, respectively. The fact that off-farm income accounts for the larger share suggests that farmers cannot obtain sufficient income only from agriculture due to petty farm size and a relatively more developed labor market. The amount of remittance received by the farm household is trivial.

The average number of years of education of farmers in Planggok and Somokaton are 7.6 and 4 years, respectively. The average numbers of family labor in both hamlets are 2.56 and 2.81 , respectively.

As for the owned farm asset, the average numbers of draft animals and machinery are very small, because the rental market for them is developed and it is less costly for the farmers to rent a tractor for cultivating their paddy field than to use one that they own.

\subsection{Labor Market Structure}

The majority of the household heads that participated in this study work as farmers (Table 2). However, the majority of other family laborers are engaged in off-farm jobs such as traders, salaried workers, daily unskilled wage laborers, etc. Traders are engaged in miscellaneous trade in their houses or in a local market which is located more or less $11.5 \mathrm{~km}$ away from the village. Most of them trade snacks, vegetables, seasonings, and rice. About $30 \%$ of the household members who are engaged in farming also have subsidiary off-farm jobs.

The permanent off-farm worker category includes factory workers who work in various kinds of factories, for instance, garment factories, plastic factories and automobile factories in Yogyakarta city or in Sleman district, while the public servant category includes primary school teachers, secondary school teachers, nurses, police and lecturers. The unskilled daily labor category includes agricultural hired laborers for transplanting, weeding, and harvesting and tractor operation.

The fact that a considerable number of off-farm job opportunities including permanent wage jobs have already been available for the villagers indicates that the labor market is developed to some extent.

Table 3 provides data on the distribution of labor in paddy farming.

According to Table 3 , the average number of family labor per hectare for Planggok was 123 man days and for Somokaton 122 man days, whereas hired labor engaged in farm household was 52 man days in Planggok and 60 man days in Somokaton. Although the average farm size is extremely small, the farmers still employ hired laborers. This is because farmers require the assistance of not only family labor but also hired labor to be able to finish transplanting and harvesting at a suitable time.

Table 2. Occupations of Farm Family Members in Planggok and Somokaton, 2002

\begin{tabular}{c|l|c|c|c|c}
\hline \hline \multirow{2}{*}{ No } & \multicolumn{2}{|c|}{ Occupation } & \multicolumn{2}{|c|}{ Major Occupation } & \multicolumn{2}{c}{ Subsidiary Occupation } \\
\cline { 3 - 6 } & $\begin{array}{c}\text { Household head } \\
\text { (person) }\end{array}$ & $\begin{array}{c}\text { Family member } \\
\text { (person) }\end{array}$ & $\begin{array}{c}\text { Household head } \\
\text { (person) }\end{array}$ & $\begin{array}{c}\text { Family member } \\
\text { (person) }\end{array}$ \\
\hline 1 & Farmer & 41 & 32 & 8 & 7 \\
2 & Non-farm self-employed & 1 & 13 & 3 & 6 \\
3 & Daily unskilled labor & 1 & 13 & 10 & 3 \\
4 & Permanent off-farm job & 2 & 23 & 0 & 0 \\
\hline
\end{tabular}

Source: Farm Household Survey, 2002.

Table 3. Labor Employed by Farmers, Crop Year 2000/2001-2002/2003

\begin{tabular}{lcc}
\hline \hline Hamlet & Family labor (man days/ha) & Hired labor (man days/ha) \\
\hline Planggok & 123 & 52 \\
Somokaton & 122 & 60 \\
Average & 122.5 & 56 \\
\hline
\end{tabular}

Source: Farm Household Survey: 2000, 2001 and 2002 
Table 4. Annual Demand for Family Labor in the Study Area, 2000/2001-2002/2003

\begin{tabular}{l|c|c}
\hline \hline \multirow{2}{*}{ Kind of Job } & \multicolumn{2}{|c}{ Average Working Days Per Year } \\
\cline { 2 - 3 } & Planggok & Somokaton \\
\hline 1. On-farm (paddy cultivation) & $55.2(33.2 \%)$ & $25.8(16.8 \%)$ \\
2. Off-farm activity: & $111.2(66.8 \%)$ & $127.7(83.2 \%)$ \\
a. Non-farm self-employed & 35.3 & 44.7 \\
b. Daily unskilled labor & 31.3 & 21.6 \\
c. Permanent off-farm job & 44.6 & 61.4 \\
Average Working Days Per Year & $166.4(100 \%)$ & $153.5(100 \%)$ \\
\hline
\end{tabular}

Source: Farm Household Survey, 2000-2002

Note: Non-farm self employed includes trading and household industry. Daily unskilled labor includes agricultural wage laborers and artisans. Meanwhile, permanent off-farm jobs includes public servants and factory workers.

Moreover, the annual demand for family labor onfarm and off-farm are shown in Table 4.

From Table 4, it can be seen that the average demand for family labor in Planggok from 2000-2002 is 166.4 working days per year per family labor. Of the average working days per year in this hamlet, 111.2 working days are allocated for off-farm activities and 55.2 working days for on-farm activities. In addition, trading and non-agricultural wage labor are the dominant off-farm activities in this hamlet.

Table 4 also shows that family labor in Somokaton utilizes 153.5 working days per year per family labor for both on-farm and off-farm activities. Just like in Planggok, off-farm work is a major activity in Somokaton, especially for non-agricultural wage labor and trading, which uses 40.2 and 39.3 working days, respectively. On the other hand, 25.8 working days are allocated for on-farm activities.

Thus, the total working days for income-earning family labor are not so small. In addition, the villagers usually spend a considerable amount of time for household activities and social activities. Therefore, this suggests that there is no sufficient evidence that surplus labor exists in this study area.

\subsection{Substitutability of on-farm family labor for off- farm labor and hired labor}

In studies testing the separation theorem, Lopez [1984], Deolalikar and Vijverberg [1987], Jacoby [1993], Udry [1996] and, Abdulai and Regmi [2000] cast doubts on two assumptions which are necessary for the validity of the separation theorem. First, farmers are presumed to be indifferent about whether they are working on their own farms or off-farm. Second, there is perfect substitution between family labor and hired labor.

In order to examine these two assumptions, we formulated the following questions for the respondents, as can be seen in Table 5 .

Table 5. Results of Interview on Working Preference and Substitution between Family and Hired Labor

\begin{tabular}{|c|c|c|c|c|}
\hline \multirow{2}{*}{ Question } & \multirow{2}{*}{ Available Answer } & \multicolumn{2}{|c|}{ Hamlet } & \multirow{2}{*}{ Total Respondent } \\
\hline & & Planggok & Somokaton & \\
\hline \multirow{3}{*}{$\begin{array}{l}\text { If you have farmland where the income earned from the } \\
\text { land is equal to work on off-farm, do you prefer to work on } \\
\text { your farm or off-farm? }\end{array}$} & On-farm & 11 & 20 & $31(68.9 \%)$ \\
\hline & Off-farm & 6 & 6 & $12(26.7 \%)$ \\
\hline & Indifferent & 1 & 1 & $2(4.4 \%)$ \\
\hline \multicolumn{2}{|l|}{ Total samples of each question } & 18 & 27 & $45(100 \%)$ \\
\hline \multirow{2}{*}{$\begin{array}{l}\text { Do you think the skill of family labor engaged in your farm } \\
\text { can be substituted perfectly by hired labor? }\end{array}$} & Yes, I do & 6 & 5 & $11(24.4 \%)$ \\
\hline & No, I do not & 12 & 22 & $34(75.6 \%)$ \\
\hline \multicolumn{2}{|l|}{ Total samples of each question } & 18 & 27 & $45(100 \%)$ \\
\hline
\end{tabular}

Source: Farm Household Survey, 2004 
Table 5 shows that more than $2 / 3$ of respondents answered that they preferred working on-farm to offfarm. These findings imply that the assumption of perfect substitutability of on-farm family labor and offfarm family labor is not realistic.

With respect to the investigation of the second assumption, we found that around $75.6 \%$ of the farmers judge that the skill of family labor cannot be replaced by hired labor. They prefer to employ family labor than hired labor. All these facts suggest that in the production function, hired labor is not perfectly substitutable for family labor.

\section{Analytical Framework}

\subsection{Theoretical Framework}

To test the separation theorem and the profitmaximization hypothesis, the utility maximization model of farm household was utilized. Considering that offfarm employment opportunities exist, the focus is on whether or not the existing demand for off-farm family labor is rationed in the labor market.

It is assumed here that output and current input markets are perfect. It is also assumed that there is no land market, following Benjamin (1992). Each household cultivates its own endowment of land.

Under the assumption of labor market rationing and imperfect substitutability of labor, the household problem is to solve

$$
\begin{aligned}
& \operatorname{Max} U \mathrm{Uh}=\mathrm{U}\left(\mathrm{c}, \mathrm{L}^{\mathrm{F}}, \mathrm{L}^{\mathrm{O}} ; \mathrm{a}\right), \ldots \ldots . . . \\
& \text { with respect to } \mathrm{c}, \mathrm{L}^{\mathrm{F}}, \mathrm{L}^{\mathrm{O}}, \mathrm{L}^{\mathrm{H}}, \mathrm{X}
\end{aligned}
$$

Subject to

$$
\begin{aligned}
& c=F\left(L^{F}, L^{H}, X ; A\right)-w L^{H}-P x X+w L^{O}+y ; \\
& \mathrm{T}(\mathrm{a}) \mathrm{L}^{\mathrm{F}}+\mathrm{L}^{\mathrm{O}} ; \mathrm{L}=\mathrm{L}^{\mathrm{F}}+\mathrm{L}^{\mathrm{H}} \text {; } \\
& \text { and } c, \mathrm{~L}^{\mathrm{O}}, \mathrm{L}^{\mathrm{H}}, \mathrm{L}^{\mathrm{F}}, \mathrm{X} \geq 0 \text {. } \\
& \mathrm{L}^{\mathrm{O}} \leq \mathrm{L}^{-}
\end{aligned}
$$

By rearranging the budget constraint, we will get

$$
c=y+\pi+w^{*} L^{F}+w L^{O}
$$

Here, the household utility function (Uh) depends on the consumption of goods (c), on leisure (1) and household characteristics (a) while satisfying quasiconcavity. $\mathrm{F}\left(\mathrm{L}^{\mathrm{F}}, \mathrm{L}^{\mathrm{H}}, \mathrm{X}: \mathrm{A}\right)$ is a concave production function, where $\mathrm{q}, \mathrm{L}, \mathrm{X}$ and $\mathrm{A}$ denote a vector of output, total labor, current input utilized on the farm, and area cultivated by the household, respectively. (L) is total labor employed on ones own farm and consists of family labor $\left(\mathrm{L}^{\mathrm{F}}\right)$ and hired labor $\left(\mathrm{L}^{\mathrm{H}}\right)$. The market prices of hired labor and off-farm family labor $\left(\mathrm{L}^{\mathrm{O}}\right)$ are assumed to be equal to $\mathrm{w} . \mathrm{L}^{\mathrm{O}}$ is constrained by the maximum amount of time, $\mathrm{L}^{-}$, as a result of labor market rationing. In addition, each household has a time endowment, $\mathrm{T}(\mathrm{a})$, which depends on family characteristics, and y is exogenous income. $\pi(\mathrm{w}, \mathrm{Px}, \mathrm{A}$, a) $=F\left(L^{F *}, L^{H *}, X^{*} ; A\right)-w^{*} L^{F *}-w L^{H *}-P x X^{*}$ is farm profit function, $\mathrm{W}$ is the market wage rate, $\mathrm{W}^{*}$ is the shadow wage rate of family labor and Px is the price of current input. All prices are normalized by output price.

The farm household chooses the levels of family labor, hired labor, off-farm labor, current input and consumption which maximize utility, subject to (2) and (3). From the first order conditions, we can derive the following two types of on-farm labor demand functions.

If (3) is binding, then $\mathrm{L}^{*}=\left(\mathrm{L}^{\mathrm{F} *}+\mathrm{L}^{\mathrm{H} *}\right)=\mathrm{L}(\mathrm{w}, \mathrm{Px}$, $\left.\mathrm{A}, \mathrm{a}, \mathrm{L}^{-}\right)$and $\mathrm{L}^{\mathrm{O} *}=\mathrm{L}^{-}$.

If not, then $\mathrm{L}^{*}=\mathrm{L}(\mathrm{w}, \mathrm{Px}, \mathrm{A}, \mathrm{a})$ and $\mathrm{L}^{0 *}=\mathrm{L}^{0}(\mathrm{w}, \mathrm{Px}$, $A, a)$.

If (3) is not binding and family labor is perfectly substitutable by hired labor and off-farm labor, then $\mathrm{L}^{*}=\mathrm{L}(\mathrm{w}, \mathrm{Px}, \mathrm{A})$.

Or if we apply Hotelling's lemma, we can derive the labor demand function from the profit function $\pi(\mathrm{w}, \mathrm{Px}$, a, $\left.A, L^{-}\right)$.

If (3) is binding, $\pi\left(w, P x, a, A, L^{-}\right) / \partial w \neq L^{*}$ and $L^{O *}$ $=\mathrm{L}^{-}$.

If not, $\partial \pi(w, P x, a, A) / \partial w \neq L^{*}$.

If not binding and family labor is perfectly substitutable for hired labor and off-farm labor, $\partial \pi(\mathrm{w}$, $\mathrm{Px}, \mathrm{A}) / \partial \mathrm{w}=\mathrm{L}^{*}$

In other words, if (3) is not binding and family labor is not perfectly substitutable by hired and off-farm labors, then both the on-farm labor demand and the off-farm labor supply are influenced by not only (w, Px, A) but also by the household characteristics (a).

In both cases, we estimated the demand function of on-farm labor and the supply function of off-farm labor as shown in (5) and (6) to examine the null hypotheses 
that family farm labor is substitutable for the other labor and/or that off-farm labor demand is binding.

\subsection{Empirical Model}

For the purpose of testing the two hypotheses, we estimated on-farm labor demand and off-farm labor supply separately.

As for the estimation of labor demand, two lines of empirical methods will be used. In the first approach, under the null hypothesis of the separation theory, the demand function of on-farm labor depends only on market wage, the other input price and the amount of fixed input. On the other hand, in the alternative hypothesis, the demand for on-farm labor and/or the supply of off-farm labor does not depend only on the

Table 6. Definitions of the Variables Used in the Analysis of the Separation Property

\begin{tabular}{|c|c|}
\hline Variables & Definition \\
\hline \multicolumn{2}{|l|}{ 1. Demand for Labor in Rice Farming } \\
\hline Pre-harvest labor demand $\left(\mathrm{L}_{\mathrm{D}}\right)$ & $\begin{array}{l}\text { Total person days (family and hired labors) for seeding and raising of seedling, } \\
\text { transplanting, fertilizer and pesticide application, irrigation, weeding, and bird } \\
\text { guarding. }\end{array}$ \\
\hline Total labor demand $\left(\mathrm{L}_{\mathrm{D}}\right)$ & $\begin{array}{l}\text { Pre-harvest labor added to plowing, harrowing, leveling \& furrowing, harvesting, } \\
\text { threshing, drying, packaging \& transport. }\end{array}$ \\
\hline Normalized planting wage rate $(\mathrm{w})^{3)}$ & $\begin{array}{l}\text { Wage bill in planting divided by the number of days of hired labor. To normalize } \\
\text { planting wage, it is divided by the producer price of a kilogram of rice. }\end{array}$ \\
\hline Normalized wage rate $(\mathrm{w})$ & $\begin{array}{l}\text { Total wage bill divided by number of days of hired labor. To normalize wage, it is } \\
\text { divided by the producer price of a kilogram of rice. }\end{array}$ \\
\hline Area harvested (A) & Total hectares of rice harvested in the given year. \\
\hline Normalized price of urea (Purean) & $\begin{array}{l}\text { Price of a kilogram of urea divided by producer price of a kilogram of rice, multiplied by } \\
100 .\end{array}$ \\
\hline Household size $\left(\mathrm{a}_{1}\right)$ & Total number of household members who live together. \\
\hline Prime males fraction $\left(\mathrm{a}_{2}\right)$ & Fraction of males of household members between $16 \& 55$ years of age \\
\hline Prime females fraction $\left(a_{3}\right)$ & Fraction of females of household members between $16 \& 55$ years of age \\
\hline Age of household head $\left(a_{4}\right)$ & Age of reported household head. \\
\hline Educ. of house. head $\left(a_{5}\right)$ & Number of successive years in school of household head. \\
\hline Remittance & $\begin{array}{l}\text { Total money and in kind remitted by household members and relatives to the farm } \\
\text { household. }\end{array}$ \\
\hline Dummy-Irrigation & $\begin{array}{l}\text { Dummy }=1 \text { if paddy field is under technical or semi-technical irrigation; otherwise the } \\
\text { dummy }=0\end{array}$ \\
\hline \multicolumn{2}{|c|}{ 2. Profit Function and Derived Demand by SUR } \\
\hline Normalized profit ( $(a)$ & Current revenue less current total variable costs and then divided by rice price. \\
\hline Normalized price of variable inputs $\left(\mathrm{q}_{\mathrm{i}}\right)$ & $\begin{array}{l}\text { Price of variable inputs (seed, urea, and labor) deflated by rice price. } i=1 \text { for seed; } i=2 \\
\text { for urea; and } i=3 \text { for labor input. }\end{array}$ \\
\hline Land service $\left(\mathrm{K}_{1}\right)$ & Total rent of farmland services divided by rice price. \\
\hline Hand tractor services $\left(\mathrm{K}_{2}\right)$ & Total cost of hand tractor services divided by rice price. \\
\hline Variable inputs $\left(\mathrm{X}_{\mathrm{i}}\right)$ & $\begin{array}{l}\text { Total amount of input used for farming where } i=1 \text { for seed, } i=2 \text { for urea, and } i=3 \text { for } \\
\text { labor. }\end{array}$ \\
\hline \multicolumn{2}{|l|}{ 3. Off-farm Labor Supply } \\
\hline Off-farm labor supply $\left(\mathrm{L}_{\mathrm{S}}\right)$ & Total working days of all household members in off-farm market \\
\hline Normalized off-farm labor wage rate $(w)$ & $\begin{array}{l}\text { Total wage bill in off-farm labor market divided by number of days of hired labor. This } \\
\text { wage is then deflated by producer price of a kilogram of rice. }\end{array}$ \\
\hline Purean, $A, a_{1}, a_{2}$, and $a_{3}$ & These variables are defined in the same way as in (1) demand for labor in rice farming. \\
\hline Elderly males fraction $\left(\mathrm{a}_{4}\right)$ & Fraction of males of household members more than 55 years of age. \\
\hline Elderly females fraction $\left(a_{5}\right)$ & Fraction of females of household members more than 55 years of age. \\
\hline Age of household head $\left(a_{6}\right)$ & Age of reported household head. \\
\hline Education of h. head $\left(a_{7}\right)$ & Number of successive years in school of household head. \\
\hline
\end{tabular}


above mentioned factors but on family characteristics as well.

Therefore, the empirical model proposed for testing the separation property is as follows:

$\ln L_{D}=\alpha_{0}+\beta_{1} \ln w+\gamma_{2} \ln A+\theta_{3} \ln$ Purean $+\partial_{4}$ $\ln \mathrm{a}_{1}+\partial_{5} \ln \mathrm{a}_{2}+\partial_{6} \ln \mathrm{a}_{3}+\ldots+\partial_{\mathrm{n}} \ln \mathrm{a}_{\mathrm{n}}+\mathrm{u}$.

For the second approach, the profit function and the derived system of factor demand are estimated simultaneously by applying the Seemingly Unrelated Regression (SUR) method ${ }^{2}$. This model decisively differs with the previous works of Kuroda and Yotopoulos [1978], in the respect that it allows onfarm family labor not to be substitutable by other labor. The empirical model of this study is specified as follows:

$$
\ln \Pi a=\ln \alpha 0+\sum_{i=1}^{3} \alpha i^{*} \ln \mathrm{q}_{\mathrm{i}}+\sum_{j=1}^{2} \beta j^{*} \ln \mathrm{K}_{\mathrm{j}}+\mathrm{d}_{\mathrm{i}} \mathrm{D} 1
$$

From the partial differentiation of profit function with respect to factor price,

$$
\frac{-q i X i}{\Pi a}=\alpha_{i}^{*}
$$

As for the off-farm labor supply function, if any household characteristic has a significant effect on off-farm labor supply, then this indicates that equation (3) is not binding.

$\ln \mathrm{L}_{\mathrm{S}}=\alpha_{0}+\beta_{1} \ln \mathrm{w}+\gamma_{2} \ln \mathrm{A}+\theta_{3} \ln$ Purean $+\partial_{4}$ $\ln \mathrm{a}_{1}+\partial_{5} \ln \mathrm{a}_{2}+\partial_{6} \ln \mathrm{a}_{3}+\ldots+\partial_{\mathrm{n}} \ln \mathrm{a}_{\mathrm{n}}+\mathrm{u}$

As for the definition of the variables used in this analysis, please refer to Table 6 .

\section{Results of Estimation}

\subsection{Testing for the Separation Hypothesis}

The F-test is used to determine whether or not an individual effect exists. The results of the F-test are presented in Table 7 .

We can see from Table 7 that the null hypotheses of no individual effect are rejected for pre-harvest labor demand, but not rejected for total labor demand. Consequently, the Ordinary Least Square (OLS) method is used for analyzing total labor demand, and it is necessary to investigate the kind of effect that exists (fixed effect or random effect) on pre-harvest labor demand by applying the Hausman test. The result indicated that random effect exists on pre-harvest labor demand.

The results of the separation property test are summarized in Table 8, with the expected signs of estimated parameters. It shows that the following variables are significant: area harvested, labor wage, urea price, household size, prime females fraction, education of household head, remittance and dummy for irrigation.

The larger the farm size, the greater the need for labor. Therefore, the expected sign for the coefficient on area harvested should be positive. Meanwhile, increase in labor wage rate will reduce the quantity of labor employed in the farm. Urea can be considered as labor saving technology. The effect of ureas price on demand for labor depends on substitutability between urea and labor. We expect this effect to be positive.

Household size, and prime males and females fractions may represent family endowment. Expanding the family endowment leads to larger demand for consumption. In this regard, household should enhance their income to fulfill their consumption. As a result, demand for labor is expected to rise. Yet, in the case of Indonesia, the main task of the female is usually to take care of their children and doing other domestic activi-

Table 7. Investigating the existence of individual effect

\begin{tabular}{llccc}
\hline \hline No & \multicolumn{1}{c}{ Kind of test } & F-calculated* & P-value & Conclusion \\
\hline 1 & Pre-harvest labor demand & 10.490 & 0.002 & Reject $\mathrm{H}_{0}$ \\
2 & Total labor demand & 0.579 & 0.448 & Not Reject $\mathrm{H}_{0}$ \\
\hline
\end{tabular}

Note: * $=\mathrm{F}(1,123)$. In general, the F-value can be obtained directly from the TSP program. The figures ' 1 ' and ' 123 ' of $\mathrm{F}(1,123)$ means numerator and denominator degrees of freedom, respectively. In addition, the figure ' 1 ' represents the number of restrictions, while the figure ' 123 ' is obtained from the number of observations minus the number of estimated parameters minus one (Wooldridge, 2003). 
Table 8. Demand for Labor in Rice Farming in Margokaton Village (Dependent Variable: log person days employed)

\begin{tabular}{|c|c|c|c|}
\hline \multirow{3}{*}{$\begin{array}{l}\text { Independent Variables } \\
\text { Constant term }\end{array}$} & \multirow{3}{*}{ Expected sign } & \multicolumn{2}{|c|}{ Coefficient Values } \\
\hline & & Pre-harvest Labor & Total Labor \\
\hline & & $-1.144 \quad(2.272)$ & $-1.653 \quad(3.112)$ \\
\hline Log (area harvested) & + & $0.332 * * *(0.061)$ & $0.229 * * *(0.069)$ \\
\hline Log (planting wage or wage) & - & -0.133 & $-0.464 * * *(0.157)$ \\
\hline Log (urea price) & + & $0.825^{* *}(0.372)$ & $0.896^{* * *} \quad(0.392)$ \\
\hline Log (household size) & + & $0.469 * *(0.184)$ & $0.520 * * *(0.168)$ \\
\hline Prime males fraction & + & -0.428 & -0.239 \\
\hline Prime females fraction & - & $-1.041 * * *(0.362)$ & -0.466 \\
\hline Age of household head & - & -0.009 & $(0.006)$ \\
\hline Education of household head & - & $-0.045^{*} \quad(0.024)$ & $-0.040^{*} \quad(0.023)$ \\
\hline Log (Remittance) & + & $(0.078)$ & $0.261^{* *}(0.106)$ \\
\hline Dummy-Irrigation & + & $0.696 * * *(0.153)$ & $0.675^{* * *}(0.145)$ \\
\hline R-squared & & 0.447 & 0.614 \\
\hline Adjusted R-squared & & 0.402 & 0.582 \\
\hline Hausman Test & & 0.052 & 0.270 \\
\hline
\end{tabular}

Note: standard errors is in parentheses

$*, * *, * * *=$ coefficient is significant at $10 \%, 5 \%$ and $1 \%$, respectively.

ties. Consequently, this effect is expected to be negative.

The more educated farm household head is expected to be more efficient in using labor. Remittance reflects exogenous income and is expected to have a positive effect on the demand for labor. Finally, increase in land productivity is expected to be in parallel with the demand for labor.

In summary, the demand for labor is influenced significantly by the following household characteristics: household size, prime females fraction, and education. As a consequence, these results suggest that the separation property hypothesis should be rejected.

\subsection{Testing for the Profit-maximization Hypothesis}

The estimation results of the Cobb-Douglas Profit and Factors Demand Functions are presented in Table 9 .

The estimation results under the non-restriction method show that the price of seed has the same sign as expected, although it is insignificant. As for the coefficients on the prices of urea and labor wage, the signs are different from our expectation, but these coefficients are also not significant. Increase in fixed inputs of production enhances the profit earned, as theory predicts, and these are shown by the coeffi- cients on land and hand tractor.

All signs of coefficients on the factors demand function are negative and statistically significant, as we expected. These results suggest that increase in price of input leads to reduced demand for its input.

To explore whether or not rice farmers behavior in Java follows the profit maximization principle, it is necessary to examine the null hypothesis of profit maximization. In this regard, the hypotheses proposed are as follows:

$\mathrm{H}_{0}: \alpha_{i}^{*}=\alpha_{i}^{* \prime}$ for $\mathrm{i}=1,2,3$ (profit maximization)

Ha: $\alpha_{i}^{*} \neq \alpha_{i}^{* \prime}$ (no-profit maximization)

To make an F-test, we calculated the F-ratio by using the estimated residuals of restricted and unrestricted equations.

$$
\text { F-ratio }=\frac{(81.0811-65.872) / 4}{65.872 /(135-6-1)}=7.388
$$

Since the calculated $\mathrm{F}$ is $>\mathrm{F}(3,128,1 \%)$, the null hypothesis of profit maximization must therefore be rejected. The rejection of the null hypothesis implies that the rice farmers in Java do not perfectly maximize their profit with respect to their utilization of variable inputs (seed, urea, and labor). Alternatively we can say that rice farmers do not equate the marginal value products of the variable inputs to their market prices. 
Table 9. Cobb-Douglas Profit and Factors Demand Functions by Seemingly Unrelated Regression

(Dependent variable: log normalized profit)

\begin{tabular}{|c|c|c|c|}
\hline \multirow{2}{*}{$\begin{array}{l}\text { Independent variables } \\
\text { Profit Function }\end{array}$} & \multirow{2}{*}{ Expected sign } & \multicolumn{2}{|c|}{ Coefficient values } \\
\hline & & No Restriction & 4 Restrictions $\alpha i^{*}=\alpha i^{*}(i=1, \ldots, 4)$ \\
\hline Constant term & & $-7.997 * * *(1.016)$ & $-6.666^{* * *}(1.379)$ \\
\hline Log (normalized price of seed) & - & $-0.016 \quad(0.177)$ & $-0.026 * * *(0.002)$ \\
\hline Log (normalized price of urea) & - & $(0.363)$ & $-0.119 * * *(0.006)$ \\
\hline Log (normalized labor wage) & - & $0.222 \quad(0.152)$ & $-0.748 * * *(0.097)$ \\
\hline Log (land service) & + & $0.669 * * *(0.071)$ & $0.667 * * *(0.099)$ \\
\hline Log (hand tractor service) & + & $0.433 * * *(0.087)$ & $0.531 * * *(0.120)$ \\
\hline D1 & + & $(0.127)$ & $0.003 \quad(0.173)$ \\
\hline$R$-squared & & 0.633 & 0.557 \\
\hline \multicolumn{4}{|l|}{ Factor Demand Function } \\
\hline Seed Demand & - & $-0.030 * * *(0.002)$ & $-0.026^{* * * *}(0.002)$ \\
\hline$R$-squared & & 0.241 & 0.241 \\
\hline Fertilizer Demand & - & $-0.129 * * *(0.007)$ & $-0.119 * * *(0.006)$ \\
\hline$R$-squared & & 0.424 & 0.424 \\
\hline Family Labor Demand & - & $-2.542 * * *(0.256)$ & $-0.748 * * *(0.097)$ \\
\hline$R$-squared & & 0.068 & 0.068 \\
\hline Hired Labor Demand & - & $-0.867 * * *(0.088)$ & $-0.748 * * * * 0.097)$ \\
\hline$R$-squared & & 0.055 & 0.055 \\
\hline F-calculated & & $7.388^{* * * *}$ & \\
\hline
\end{tabular}

Note: standard errors are given in parentheses

$*, * *, * *=$ coefficient is significant at $10 \%, 5 \%$ and $1 \%$, respectively.

These results thus support the conclusion of previous analysis which rejects the separation property.

In addition, the difference of estimated parameters for family-labor demand between non-restriction and restriction is significantly large. This also suggests that the marginal productivity of family labor is significantly different from the market wage.

\subsection{Testing off-farm labor constraint}

The results of testing off-farm labor constraint are presented in Table 10, with the expected signs of estimated parameters. Off-farm wage is expected to have a positive effect on workdays in off-farm jobs because off-farm and on-farm jobs are substitutable. Farm size is expected to have a positive correlation with demand for labor in farming and hence it is expected to have a negative correlation with off-farm family labor supply. Meanwhile, a rise in the price of urea will cause the demand for this input to reduce and at the same time it increases the demand for onfarm labor due to substitution effect. As a result, this condition is expected to decrease off-farm labor supply.

Family size is closely related to demand for consumption. Households with larger numbers of family members need more income, hence this coefficient is expected to have a positive sign. This is also true for the coefficients on prime males and females fractions as well as for those on elderly males and females fractions.

As the age of laborers increases, we can expect their labor supply to diminish. Education usually correlates positively with probability of off-farm labor supply. Yet, Sumner (1982) pointed out that this effect was negative. Therefore, the expected sign of education may be either positive or negative.

Table 10 shows that the estimated parameter of wage in off-farm labor market, log (off-farm wage), and all the variables related to household characteristics, $\log$ (household size), prime males fraction, prime females fraction, elderly males fraction, and elderly females fraction, as well as age and education, are 
Table 10. Off-Farm Labor Supply in Margokaton Village (Dependent variable: log work days in off-farm job)

\begin{tabular}{lccc}
\hline \hline \multicolumn{1}{c}{$\begin{array}{c}\text { Independent } \\
\text { variables }\end{array}$} & $\begin{array}{c}\text { Expected } \\
\text { sign }\end{array}$ & \multicolumn{2}{c}{$\begin{array}{c}\text { Coefficient } \\
\text { values }\end{array}$} \\
\hline Constant term & & $6.070^{* *}(2.553)$ \\
Log (Off-farm wage) & + & $0.655^{* * *}(0.216)$ \\
Log (Area harvested) & - & -0.062 & $(0.085)$ \\
Log (Purean) & - & $-0.680 \quad(0.487)$ \\
Log (Household size) & + & $1.331^{* * *}(0.289)$ \\
Prime males fraction & + & $1.485^{* *}(0.749)$ \\
Prime females fraction & + & $2.673^{* * *}(0.746)$ \\
Elderly males fraction & + & $2.486^{* * *}(0.808)$ \\
Elderly female fraction & + & $3.402^{* * *}(0.945)$ \\
Age & - & $-0.032^{* * *}(0.001)$ \\
Education & $?$ & $-0.063^{*} \quad(0.034)$ \\
R-squared & & 0.289 \\
Adjusted R-squared & & 0.220 \\
Hausman Test & & $0.43440 \mathrm{E}-01$ \\
\hline
\end{tabular}

Note: standard errors are given in parentheses

$*, * *, * * *=$ coefficient is significant at $10 \%, 5 \%$ and $1 \%$, respectively.

statistically significant. Since household characteristics have a significant impact on off-farm labor supply, we therefore suggest that off-farm labor market in rural Java is not a binding constraint.

\section{Conclusion and Policy Implication}

The separation hypothesis and/or the profit maximization hypothesis have usually been rejected in developing countries except in Indonesia. This paper reexamined those hypotheses on the basis of case studies in rural Java.

In our study, those hypotheses are rejected but the hypothesis of no binding constraint in off-farm labor market is not rejected. In other words, the two hypotheses are rejected not because off-farm labor market is rationed but because on-farm family labor is not substitutable by off-farm labor and hired labor.

These results are different from the previous studies using Indonesian data, such as those of Benjamin [1992], and Pitt and Rosenzweig [1986], which did not reject the hypotheses. However, our results are consistent with their main findings of no binding constraint on off-farm employment in the casual labor market.

These findings suggest that household members in rural Java can find sufficient off-farm employment opportunities. Farmland, which is the scarcest resource in rural Java, is an invaluable asset for farm households so farmers do not like to part with their land. Putting our findings together with this fact, it is highly possible that small farmers will choose not to withdraw from farming but to continue part-time farming to maximize the present value of their household income, even though structural policies which aim to enlarge farm size and to increase productivity of agricultural sector will be implemented. As a result, such agricultural policies might fail to achieve their objectives.

Negotiations for trade liberalization such as bilateral FTA, WTO agreement have been started. If the Indonesian government is to agree to opening the domestic market of agricultural products, it must implement certain agricultural policies to strengthen the global competitiveness of its agricultural sector. However, if such agricultural policies in fact turn out to be ineffective as mentioned earlier, the government should be very careful in liberalizing international trade of its agricultural products because povertyrelated issues remain a serious concern in these rural areas.

Finally, this study is a crucial step in elucidating the relationship between farm household behavior and market structure in rural Java. However, much more work needs to be done and more research on this topic has to be conducted.

The assumption of casual off-farm labor market, which was discussed in this study, should be reconsidered. It may be relevant to use a farm household model in which household members do not choose working hours but make a decision whether they participate in the labor market or not because the opportunities for permanent jobs with rigid working hours have been increasing. Therefore, an important item on our future research agenda is to consider a more realistic agricultural household model for rural Java. 


\section{Acknowledgements}

We wish to thank the JSPS-DGHE Core University Program in Applied Bioscience in Indonesia, and the Government of Japan which provided the funds for conducting this research. We also thank Prof. Hiroshi Tsujii, Prof. Noriaki Iwamoto, Prof. Hitoshi Yonekura, Dr. Slamet Hartono, Dr. Irham and other participants of the Seminar on "Socio-Economic Studies on Sustainable Development in Rural Indonesia", held at The University of Tokyo, 2004 for their fruitful comments and encouragement. We are grateful to two anonymous referees for their valuable comments and suggestions. However, all shortcomings and errors that remain are our responsibility.

\section{Notes}

1) In the case of postwar Japan, economic development led to the creation of part-time farmers rather than large numbers of people abandoning farming and the formation of viable large scale farm units, this in spite the fact that the Japanese government had implemented the 1961 Agricultural Basic Law that aimed to create farmers who were devoted to agriculture and were capable of securing an income on a par with that of city laborers. See Mori [1991] and Nakayasu [1991].

2) We used SUR because this is the standard method to estimate this type of simultaneous equation system when disturbances might be correlated, and as far as we know there is nothing in the literature to indicate that SUR is inferior to the other methods for the estimation of simultaneous equation. See Green [2000], ch. 15.

3) Planting wage is an independent variable used for estimating demand for pre-harvest labor; meanwhile, wage is an independent variable used for estimating demand for total labor. For definitions of the two kinds of wage, please refer to Table 6 .

\section{References}

[1] Abdulai, A. and P.P. Regmi, "Estimating Labor Supply of Farm Households Under Nonseparability: Empirical Evidence from Nepal", Agricultural Economics, Vol. 22 (2000), pp. 309-320.

[2] Benjamin, D., "Household Composition, Labor Market, and Labor Demand: Testing for Separation in Agricultural Household Models", Econometrica, Vol. 60, No. 2 (1992), pp. 287-322.

[3] Benjamin, D., "Can Unobserved Land Quality Explain the Inverse Productivity Relationship?", Journal of Development Economics, Vol. 46 (1995), pp. 51-84.

[4] Deolalikar, A.B. and P.M. Vijverberg, "A Test of Heterogeneity of Family and Hired Labor in Asian Agriculture", Oxford Bulletin of Economics and Statistics, Vol. 49, No. 3 (1987), pp. 291-305.

[5] Fukui, S., S. Hartono and N. Iwamoto, "Risk and Rice Farming Intensification in Rural Java", The Japanese Journal of Rural Economics, Vol. 4 (2002), pp. 32-43.

[6] Fukui, S., "Agricultural Development", (in Japanese) in Yasukichi Yasuba (ed.), Socio-economic Development of Southeast Asia (Tokyo: Keisoushobo, 2005), pp. 23-52.

[7] Green, W.H., Econometric Analysis, Prentice Hall International, Inc. (2000).

[8] Jacoby, H.G., "Shadow Wages and Peasant Family Labor Supply: An Econometric Application to the Peruvian Sierra", Review of Economic Studies, Vol. 60 (1993), pp. 903-921.

[9] Kuroda, Y., "A Study of the Firms Production Behavior in the Mid-1960's in Japan: A Profit Function Approach", The Economic Studies Quarterly, Vol. 30, No. 2 (1979), pp 107-122.

[10] Kuroda, Y. and P.A. Yotopoulos, "A Microeconomic Analysis of Production Behavior of the Farm Household in Japan: A Profit Function Approach", Keizai Kenkyu (The Economic Review), Vol. 29, No. 2 (1978), pp. 116-129.

[11] Lopez, R.E., "Estimating Labor Supply and Production Decisions of Self-Employed Farm Producers", European Economic Review, Vol. 24 (1984), pp. 61-82.

〔12〕 Mori, T., "The History of Japanese Agriculture", The Committee for the Japanese Agriculture Session XXI IAAE Conference, ed., Agriculture and Agricultural Policy in Japan (Tokyo: Tokyo University Press, 1991), pp. 3-14.

[13] Nakayasu, S., "Japan's Agricultural Structure: Characteristics and Changes", The Committee for the Japanese Agriculture Session XXI IAAE Conference, ed., Agriculture and Agricultural Policy in Japan (Tokyo: Tokyo University Press, 1991), pp. 143-158.

[14] Pitt, M.M. and M.R. Rosenzweig, "Agricultural Prices, Food Consumption, and the Health and Productivity of Indonesian Farmers", in I. Singh, L. Squire, and J. Strauss (eds.), Agricultural Household Models: Extensions, Applications, and Policy, The World Bank (1986), pp. 153-180. 
15] Strauss, J., "Does Better Nutrition Raise Farm Productivity?”, Journal of Political Economy, Vol. 94, No. 2 (1986), pp. 297-320.

[16] Strauss, J. and D. Thomas, "Human Resources: Empirical Modeling of Household and Family Decisions", in J. Behrman and T.N. Srinivasan (eds.), Handbook of Development Economics vol. IIIA (1995), pp. 1883-2023.

[17] Subejo and N. Iwamoto, "Labor Institutions in Rural
Java: A Case Study in Yogyakarta Province", In Proceedings of the $2^{\text {nd }}$ Seminar: Toward Harmonization between Development and Environmental Conservation in Biological Production, The University of Tokyo (2003).

[18] Udry, C., "Efficiency and Market Structure: Testing for Profit Maximization in African Agriculture", Unpublished paper (1996)

(受理日：2006 年 6 月 26 日) 